\title{
Response of Sowing Methods and Different Levels of Sulphur and Boron on Growth and Yield of Yellow Sarson (Brassica compestris L.)
}

\author{
Hemkalyan Verma ${ }^{1 *}$ and Joy Dawson ${ }^{2}$ \\ ${ }^{1}$ Department of Agronomy, Palli Shiksha Bhavana (Institute of Agriculture), Visva-Bharati, \\ Sriniketan, West Bengal - 731236, India \\ ${ }^{2}$ Department of Agronomy, Allahabad School of Agriculture, Sam Higginbottom Institute of \\ Agriculture, Technology and Sciences, Allahabad-211007, (U.P.), India \\ *Corresponding author
}

\begin{tabular}{|c|c|}
\hline \multicolumn{2}{|r|}{ A B S T R A C T } \\
\hline & \multirow{5}{*}{$\begin{array}{l}\text { A field experiment was carried out during the winter season of } 2013-14 \text { at the Crop } \\
\text { Research Farm, Department of Agronomy, Allahabad School of Agriculture, SHUATS, } \\
\text { Allahabad (U.P.) entitled "Response of sowing methods and different levels of sulphur and } \\
\text { boron on growth and yield of yellow sarson (Brassica compestris L.)." The experiment } \\
\text { was laid out in Randomized Block Design with twelve treatments and replicated thrice. } \\
\text { The plot consisted of three levels of sulphur }\left(15,30 \text { and } 45 \mathrm{~kg} \mathrm{ha}^{-1}\right) \text {, two levels of boron }(1 \\
\left.\text { and } 2 \mathrm{~kg} \mathrm{ha}^{-1}\right) \text { with two sowing methods (line sowing and broadcasting) along with NPK } \\
\text { each at } 80: 40: 40 \mathrm{~kg} \mathrm{ha}^{-1} \text { respectively, the results revealed that the maximum plant height } \\
(101.28 \mathrm{~cm}) \text {, plant dry weight }(19.62 \mathrm{~g}) \text {, maximum no. of branches }(9.93) \text {, test weight } \\
\left.(3.18 \mathrm{~g}) \text {, seed yield }\left(1.74 \mathrm{t} \mathrm{ha}^{-1}\right) \text {, oil yield }\left(755 \mathrm{~kg} \mathrm{ha}^{-1}\right) \text { and harvest index ( } 41.90 \%\right) \\
\text { recorded in the treatment }\left(\mathrm{T}_{5}\right) \text { sulphur } 30 \mathrm{~kg} \mathrm{ha}^{-1} \text { and boron } 2 \mathrm{~kg} \mathrm{ha}^{-1} \text { with line sowing } \\
\text { However, maximum oil content }(44.21 \%) \text { recorded in the treatment } \mathrm{T}_{6}-\text { sulphur } 45 \mathrm{~kg} \text { ha- } \\
+ \text { boron } 2 \mathrm{~kg}^{-1} \text { with line sowing. The highest benefit cost ratio }(1.82) \text { was obtained in } \\
\text { treatment }\left(\mathrm{T}_{7}\right) \text { Sulphur } 15 \mathrm{~kg} \mathrm{ha}^{-1} \text { and boron } 1 \mathrm{~kg} \mathrm{ha}^{-1} \text { with broadcasting. }\end{array}$} \\
\hline Keywords & \\
\hline $\begin{array}{l}\text { Boron level, } \\
\text { Sowing methods, } \\
\text { Sulphur level, } \\
\text { Yellow sarson }\end{array}$ & \\
\hline Article Info & \\
\hline $\begin{array}{l}\text { Accepted: } \\
12 \text { February } 201 \\
\text { Available Onlin } \\
10 \text { March } 2018\end{array}$ & \\
\hline
\end{tabular}

\section{Introduction}

Yellow sarson (Brassica compestris L.) is important oilseed crop of family cruciferae and occupies a prominent place among oilseed crops being next to groundnut in important. The present area, production and yield of nine oilseeds in India is around 26.48 million hactares, 30.94 million tonnes and $1168 \mathrm{~kg}$ per hactare respectively, and rapeseed mustard sown area in India is 6.36 million hectare which has a production of 8.03 million
tonnes.(Directorate of Economics and Statistics, Department of Agriculture and Cooperation, 2012-13). The average productivity of rapeseed-mustard in India is only $1145 \mathrm{~kg} \mathrm{ha}^{-1}$, which needs to be enhanced upto $2562 \mathrm{~kg} \mathrm{ha}^{-1}$ by 2030 for ensuring edible oil self-reliance (DRMR, 2011). Rapeseed and mustard crops are of particular significance of Rajasthan and Uttar Pradesh, which shares about $80 \%$ of area and production of entire country. The oil content of the yellow sarson seeds ranges from 35-48 \% (By NIIR Board) 
and $37-42 \%$ protein in cake (Nagaraj, 1995). It is well known that sulphur is only next to nitrogen in the nutrition of Brassica crops. Sulphur promotes oil synthesis, besides being an important constituent of seed protein, amino acid, enzymes, glucosinolate and chlorophyll (Holmes, 1980). In terms of agronomic efficiency, each kilogram of $\mathrm{S}$ increases the yield of mustard by $7.7 \mathrm{~kg}$ (Katyal et al., 1997). Rapeseed-mustard crops are particularly sensitive to sulphur deficiency mainly due to the fact that $S$ plays an important role in the chemical composition of seed and increases the percentage of oil content of seed (Khan et al., 2002).Recent advances in B research have greatly improved an understanding for B uptake and transport processes (Brown et al., 2002; Frommer and Von Wiren, 2002; Takano et al., 2002), and roles of B in cell wall formation (Matoh, 1997; O, Neill et al., 2004), cellular membrane functions (Goldbach et al., 2001), and anti-oxidative defense systems (Cakmak and Romheld, 1997). Reproductive growth, especially flowering, fruit and seed set is more sensitive to boron (B) deficiency than vegetative growth (Dear and Lipsett, 1987, Noppakoonwong et al., 1997). Thus, B fertilization is necessary for improvement of crop yield as well as nutritional quality. Mustard as a Brassica crop is very responsive to B application (Mengel and Kirkby, 1987).

\section{Materials and Methods}

The experiment was carried out during rabi season 2013-14 at Crop Research Farm, Department of Agronomy, Allahabad School of Agriculture, Sam Higginbottom University of Agriculture, Technology and Sciences, Allahabad (U.P.). Which is located at $25^{\circ} 24^{\prime}$ 42" N latitude, $81^{\circ} 50^{\prime} 56^{\prime \prime}$ E longitude and 98 $\mathrm{m}$ altitude above the mean sea level. The soil was sandy loam, $\mathrm{pH}$ of soil was 7.4 with $0.39 \%$ organic $\mathrm{C}$, having available $\mathrm{N}, \mathrm{P}, \mathrm{K}$ (185.5, 36 and $98 \mathrm{~kg} \mathrm{ha}^{-1}$ respectively). The experiment was laid out in randomized block design (factorial) with three replications, having three factors are sowing methods (line sowing and broadcasting), sulphur levels (15, 30 and $45 \mathrm{~kg} \mathrm{ha}^{-1}$ ) and boron levels (1 and 2 $\left.\mathrm{kg} \mathrm{ha}^{-1}\right)$. Half dose of nitrogen $\left(40 \mathrm{~kg} \mathrm{ha}^{-1}\right)$ and full dose of phosphorus and potash each $40 \mathrm{~kg}$ $\mathrm{ha}^{-1}$ was applied basal and remaining half dose of nitrogen $\left(40 \mathrm{~kg} \mathrm{ha}^{-1}\right)$ was applied after the first irrigation. There were total 12 treatment combinations in all. The net subplot size was 3 $\mathrm{m} \times 3 \mathrm{~m}$. All other agronomic practices i.e. thinning, hoeing, eradication of weeds and irrigation was kept same for all treatments. Yellow sarson variety 'PeelaSona' was sown. The line sowing was done at a spacing of $30 \times$ $10 \mathrm{~cm}$. B: $\mathrm{C}$ ratio considering the prevailing market price of produce and cost of cultivation. Where, T1 (S $15 \mathrm{~kg} \mathrm{ha}^{-1}+\mathrm{B} 1 \mathrm{~kg}$ $\mathrm{ha}^{-1}$ (line sowing)), T2 (S $30 \mathrm{~kg} \mathrm{ha}^{-1}+\mathrm{B} 1 \mathrm{~kg}$ $\mathrm{ha}^{-1}$ (line sowing)), T3 (S $45 \mathrm{~kg} \mathrm{ha}^{-1}+\mathrm{B} 1 \mathrm{~kg}$ $\mathrm{ha}^{-1}$ (line sowing)), T4 (S $15 \mathrm{~kg} \mathrm{ha}^{-1}+\mathrm{B} 2 \mathrm{~kg}$ $\mathrm{ha}^{-1}$ (line sowing)), T5 (S $30 \mathrm{~kg} \mathrm{ha}^{-1}+\mathrm{B} 2 \mathrm{~kg}$ $\mathrm{ha}^{-1}$ (line sowing)), T6 (S $45 \mathrm{~kg} \mathrm{ha}^{-1}+\mathrm{B} 2 \mathrm{~kg}$ $\mathrm{ha}^{-1}$ (line sowing)), T7 (S $15 \mathrm{~kg} \mathrm{ha}^{-1}+\mathrm{B} 1 \mathrm{~kg}$ $\mathrm{ha}^{-1}$ (Broadcasting)), T8 (S $30 \mathrm{~kg} \mathrm{ha}^{-1}+\mathrm{B} 1 \mathrm{~kg}$ $\mathrm{ha}^{-1}$ (Broadcasting)), T9 (S $45 \mathrm{~kg} \mathrm{ha}^{-1}+\mathrm{B} 1 \mathrm{~kg}$ $\mathrm{ha}^{-1}$ (Broadcasting)), T10 (S $15 \mathrm{~kg} \mathrm{ha}^{-1}+\mathrm{B} 2 \mathrm{~kg}$ $\mathrm{ha}^{-1}$ (Broadcasting)) T11 (S $30 \mathrm{~kg} \mathrm{ha}^{-1}+\mathrm{B} 2 \mathrm{~kg}$ $\mathrm{ha}^{-1}$ (Broadcasting)), T12 (S $45 \mathrm{~kg} \mathrm{ha}^{-1}+\mathrm{B} 2 \mathrm{~kg}$ $\mathrm{ha}^{-1}$ (Broadcasting)).

\section{Results and Discussion}

\section{Growth characters}

Growth characters are tabulated in table 1. Growth parameters of yellow sarson, viz. plant height, branches plant $^{-1}$, dry matter accumulation (DMA), crop growth rate (CGR) and relative growth rate (RGR) were influenced by different sowing methods, sulphur and boron levels. The maximum plant height $(101.28 \mathrm{~cm})$ was recorded in the treatment $\mathrm{T}_{5}$-Line sowing $+30 \mathrm{~kg}$ sulphur +2 $\mathrm{kg}$ boron $\mathrm{ha}^{-1}$, which was significantly 
superior to all other treatments. The maximum dry weight $(19.62 \mathrm{~g})$ plant $^{-1}$ and number of branches (9.93) plant $^{-1}$ were recorded in the treatment $\mathrm{T}_{5}$-Line sowing $+30 \mathrm{~kg}$ sulphur and $2 \mathrm{~kg}$ boron $\mathrm{ha}^{-1}$ as compared to all other treatments. However, the plant height, dry matter accumulation and branches plant ${ }^{-1}$ were found non-significant. The results are in agreement with those of Sharma et al., (2008) who reported that higher dry matter accumulation and plant height were also recorded higher under the border method. Budzynski, and Jankowski, (2001) also reported that the application of supplementing NPK with sulphur $\left(30 \mathrm{~kg} \mathrm{ha}^{-1}\right)$ or Mg had no effect on the stand architecture and morphological features of white mustard (Sinapsis alba). Sharma et al., (2008) who reported that higher dry matter accumulation was recorded at application of $15 \mathrm{~kg} \mathrm{~S}$ and 80 $\mathrm{kg} \mathrm{N} \mathrm{ha}{ }^{-1}$. Hossain et al.,(2011) who observed that the optimum rate of $\mathrm{B}$ was found to be 1 $\mathrm{kg} \mathrm{ha}^{-1}$ and between 1 and $2 \mathrm{~kg} \mathrm{ha}^{-1}$ boron was no significant difference. Kumar et al., (2012) found that the increasing levels of sulphur and phosphorus enhanced the growth, plant height and yield attributes showed maximum increase at $30 \mathrm{~kg} \mathrm{~S} \mathrm{ha}^{-1}$ and $45 \mathrm{~kg} \mathrm{P}_{2} \mathrm{O}_{5} \mathrm{ha}^{-1}$, respectively.

Hassan and Malhi (2011) reported that a combination of $60 \mathrm{~kg} \mathrm{~K}+30 \mathrm{~kg} \mathrm{~S}^{-1}$ would accelerate phonological development and improve seed quality of rape and mustard. Khan et al., (2008) investigated the efficiency of $\mathrm{GA}_{3}$ at 0 or $10^{-5}$ with different $\mathrm{S}$ levels $(0$, 25,50 and $75 \mathrm{~kg} \mathrm{ha}^{-1}$ ). The maximum $\mathrm{S}$ use efficiency was recorded with $25 \mathrm{~kg} \mathrm{~S}^{-1}{ }^{-1}$. The maximum crop growth rate $\left(4.69 \mathrm{gm}^{-2} \mathrm{day}^{-1}\right)$ and relative growth rate $\left(0.28 \mathrm{gg}^{-1} \mathrm{day}^{-1}\right)$ recorded in the treatment $\mathrm{T}_{3}$-Line sowing+ sulphur $45 \mathrm{~kg}+$ boron $1 \mathrm{~kg} \mathrm{ha}^{-1}$. The results are in agreement with those of Lal and Singh (2012) reported that application of sulphur and boron levels enhanced significantly all the growth parameters at higher doses i.e. $50 \mathrm{~kg} \mathrm{~S}$ $\mathrm{ha}^{-1}$ and $1.5 \mathrm{~kg} \quad \mathrm{~B} \quad \mathrm{ha}^{-1}$, respectively. Application of various nutrients increased the dry matter accumulation of the crop plant and hence, other growth indices like CGR, RGR and NAR values were recorded highest at the initial growth stages and declined thereafter. The results are in also agreement with those of Verma et al., (2009) reported that agronomic efficiency and apparent recovery was maximum at $60 \mathrm{~kg} \mathrm{~N} \mathrm{ha}^{-1}$ and $15 \mathrm{~kg} \mathrm{Sha}^{-1}$ and it declined with further increases in the levels of $\mathrm{N}$ and $\mathrm{S}$. optimum economic dose of $\mathrm{N}$ 39.5-46.3 $\mathrm{kg} \mathrm{ha}^{-1}$ and $24.5 \mathrm{~kg} \mathrm{~S} \mathrm{ha}^{-1}$.

\section{Yield characters}

Yield is tabulated in table 2. Results revealed that the seed yield, stover yield, oil content, oil yield, harvest index and test weight of yellow sarson increased non-significantly due to sowing methods, sulphur and boron levels. However, harvest index was significantly increased due to sowing methods, sulphur and boron levels. The maximum seed yield $\left(1.74\right.$ tha $\left.^{-1}\right)$, oil yield $\left(755 \mathrm{~kg} \mathrm{ha}^{-1}\right)$, harvest index $(41.90 \%)$ and test weight $(3.18 \mathrm{~g})$ were recorded in the treatment $\mathrm{T}_{5}$-Line sowing + sulphur $30 \mathrm{~kg}+$ boron $2 \mathrm{~kg} \mathrm{ha}^{-1}$. While, minimum seed yield $\left(1.53\right.$ tha $\left.^{-1}\right)$ was found in the treatment $\mathrm{T}_{8}$-Broadcasting + sulphur 30 $\mathrm{kg} \mathrm{ha}^{-1}+$ boron $1 \mathrm{~kg} \mathrm{ha}^{-1}$. The highest stover yield $\left(2.70 \mathrm{t} \mathrm{ha}^{-1}\right)$ was recorded in the treatment $\mathrm{T}_{7}$-Broadcasting + sulphur 15 $\mathrm{kg}+$ boron $1 \mathrm{~kg} \mathrm{ha}^{-1}$. However, it was also found non-significant. The maximum oil content $(44.21 \%)$ was recorded in the treatment $\mathrm{T}_{6}-$ Line sowing + sulphur $45 \mathrm{~kg} \mathrm{ha}^{-}$ ${ }^{1}+$ boron $2 \mathrm{~kg} \mathrm{ha}^{-1}$. Dry matter production and its transformation into economic yield is the ultimate outcome of various physiological, biochemicals, phenological and morphological events occurring in the plant system. Seed yield of a variety is the result of interplay of its genetic makeup and environmental factors in which plant grow. 
Table.1 Response of sowing methods and different levels of sulphur and boron on growth characters of yellow sarson

\begin{tabular}{|c|c|c|c|c|c|}
\hline Treatment & $\begin{array}{l}\text { Plant height } \\
(\mathrm{cm})\end{array}$ & $\begin{array}{l}\text { Plant dry } \\
\text { weight (g) }\end{array}$ & $\begin{array}{c}\text { No. of branches } \\
\text { plant }^{-1}\end{array}$ & $\begin{array}{l}\text { CGR (gm } \\
{ }_{2} \text { day }^{-1}\end{array}$ & $\begin{array}{l}\text { RGR (gg- } \\
{ }_{\text {day }^{-1}}\end{array}$ \\
\hline$T_{1}$ & 97.45 & 18.93 & 9.20 & 3.15 & 0.18 \\
\hline$T_{2}$ & 98.88 & 17.85 & 9.40 & 3.79 & 0.21 \\
\hline$\overline{T_{3}}$ & 98.06 & 19.08 & 9.46 & 4.69 & 0.28 \\
\hline$\overline{T_{4}}$ & 97.80 & 18.22 & 9.33 & 3.19 & 0.18 \\
\hline$T_{5}$ & 101.28 & 19.62 & 9.93 & 1.77 & 0.09 \\
\hline$T_{6}$ & 100.76 & 17.64 & 9.80 & 0.52 & 0.18 \\
\hline$\overline{T_{7}}$ & 100.25 & 19.41 & 9.26 & 2.17 & 0.11 \\
\hline$\overline{T_{8}}$ & 98.11 & 17.93 & 9.26 & 2.87 & 0.17 \\
\hline$T_{9}$ & 98.62 & 17.57 & 9.40 & 0.60 & 0.03 \\
\hline$T_{10}$ & 100.34 & 18.29 & 9.00 & 2.49 & 0.13 \\
\hline $\mathbf{T}_{11}$ & 99.16 & 18.35 & 9.06 & 2.30 & 0.16 \\
\hline$T_{12}$ & 97.10 & 17.01 & 9.00 & 1.56 & 0.09 \\
\hline SEm \pm & 2.92 & 1.22 & 0.51 & 1.33 & 0.10 \\
\hline $\begin{array}{c}C D \\
(P=0.05)\end{array}$ & - & - & - & - & - \\
\hline
\end{tabular}

Table.2 Response of sowing methods and different levels of sulphur and boron on yield, oil content, harvest index, test weight and $\mathrm{B}$ : C ratio of yellow sarson

\begin{tabular}{|c|c|c|c|c|c|c|c|}
\hline Treatment & $\begin{array}{c}\text { Seed } \\
\text { yield } \\
\left(\text { tha }^{-1}\right) \\
\end{array}$ & $\begin{array}{c}\text { Stover } \\
\text { yield } \\
\left(\text { tha }^{-1}\right)\end{array}$ & $\begin{array}{l}\text { Oil yield } \\
\text { (kgha-1) }\end{array}$ & $\begin{array}{c}\text { Oil } \\
\text { content } \\
(\%)\end{array}$ & $\begin{array}{c}\text { Harvest } \\
\text { index } \\
(\%)\end{array}$ & $\begin{array}{c}\text { Test } \\
\text { weight } \\
\text { (g) }\end{array}$ & $\begin{array}{l}\text { B:C } \\
\text { ratio }\end{array}$ \\
\hline$T_{1}$ & 1.59 & 2.50 & 681.63 & 42.87 & 37.66 & 2.98 & 1.80 \\
\hline$T_{2}$ & 1.67 & 2.45 & 721.60 & 43.21 & 39.80 & 2.90 & 1.74 \\
\hline $\mathbf{T}_{3}$ & 1.63 & 2.33 & 711.33 & 43.64 & 39.95 & 2.95 & 1.58 \\
\hline $\mathrm{T}_{4}$ & 1.64 & 2.49 & 706.67 & 43.09 & 38.97 & 2.86 & 1.73 \\
\hline$T_{5}$ & 1.74 & 2.26 & 755.50 & 43.42 & 41.90 & 3.18 & 1.68 \\
\hline$\overline{T_{6}}$ & 1.65 & 2.29 & 729.46 & 44.21 & 40.98 & 3.10 & 1.50 \\
\hline$T_{7}$ & 1.60 & 2.70 & 658.56 & 41.16 & 36.77 & 2.70 & 1.82 \\
\hline $\mathrm{T}_{8}$ & 1.53 & 2.67 & 642.60 & 42.00 & 36.43 & 2.75 & 1.61 \\
\hline$T_{9}$ & 1.64 & 2.64 & 691.91 & 42.19 & 37.88 & 2.76 & 1.60 \\
\hline $\mathbf{T}_{10}$ & 1.57 & 2.68 & 649.66 & 41.38 & 36.94 & 2.72 & 1.67 \\
\hline$T_{11}$ & 1.62 & 2.63 & 689.14 & 42.54 & 37.53 & 2.80 & 1.59 \\
\hline $\mathbf{T}_{12}$ & 1.60 & 2.63 & 683.04 & 42.69 & 37.68 & 2.84 & 1.47 \\
\hline SEm \pm & 1.88 & 0.26 & 0.42 & 1.11 & 0.01 & 0.24 & - \\
\hline $\begin{array}{c}\text { CD } \\
(P=0.05)\end{array}$ & - & - & - & - & 0.03 & - & - \\
\hline
\end{tabular}


These results and probable reasons for such results are in conformity with the findings of Sarkees, (2013) reported that crop grown with drill-row sowing method showed significantly highest seed yield as compare to broadcasting. Kumar et al., (2002) also reported that the application of $25 \mathrm{~kg} \mathrm{~S}$ ha $^{-1}$ significantly increased the yield attributes (siliqua plant $^{-1}$, seeds siliqua ${ }^{-1}$ and 1000 seed weight). Rashid et al., (2012) reported that yield and yield contributing characters increased significantly with the increased rate of boron application up to $1.5 \mathrm{~kg} \mathrm{~B} \mathrm{ha}^{-1}$. Tomar et al., (2007) also reported that sulphur application up to $30 \mathrm{~kg}$ $\mathrm{ha}^{-1}$ significantly improved the yield attributes, seed yield, stover yield, oil yield and oil content. Dabhi et al., (2010) also showed that the maximum growth, yield attributes and uptake of $\mathrm{S}$ under, $40 \mathrm{~kg} \mathrm{~S} \mathrm{ha}^{-1}$ ultimately result in the highest seed yield of mustard. Verma et al., (2012) observed the effect of S (0, 20, 40 and $\left.60 \mathrm{~kg} \mathrm{~S}^{-1}\right)$, Zinc $\left(0,5\right.$ and $\left.10 \mathrm{~kg} \mathrm{Zn} \mathrm{ha}^{-1}\right)$ and $\mathrm{B}(0,0.5$ and 1.0 $\mathrm{kg} \mathrm{B} \mathrm{ha}{ }^{-1}$ ) levels on quality, economics and uptake of nutrients in mustard.

Result revealed that application of $60 \mathrm{~kg} \mathrm{~S}$ ha ${ }^{1}$ and $1.0 \mathrm{~kg} \mathrm{~B} \mathrm{ha}^{-1}$ significantly increased seed yield, economics and oil yield over the control. Among treatment combinations of yellow sarson under sowing methods, sulphur and boron levels, the highest $\mathrm{B}$ : C ratio (1.82) was obtained in treatments $\mathrm{T}_{7}$ broadcasting $+15 \mathrm{~kg}$ sulphur and $1 \mathrm{~kg}$ boron $\mathrm{ha}^{-1}$.The results and probable reasons for such results are in conformity with the findings of Sahu et al., (2004) reported the highest net monetary returns and benefit: cost ratio were

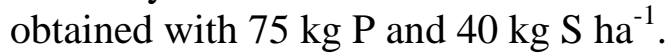

Application of Sulphur at $30 \mathrm{~kg} \mathrm{ha}^{-1}$ and Boron at $2 \mathrm{~kg} \mathrm{ha}^{-1}$ along with recommended dose of nutrients ( $\mathrm{N}$ at $80, \mathrm{P}_{2} \mathrm{O}_{5}$ at 40 and $\mathrm{K}_{2} \mathrm{O}$ at $40 \mathrm{~kg} \mathrm{ha}^{-1}$ ) with line sowing recorded highest growth and yield. Since the data is based on the study concluded in one season, the experiment may be repeated to confirm the findings.

\section{References}

Brown, R. H., 1989. Growth of the green plant, In M. B. Tesar (eds.) physiological basis of the crop growth and development. American Society of Agronomy, Madison, Wisconsin, pp. 153-174.

Budzynsky, W., Jankowaski, K., 2001. Effect of fertilization with sulphur, magnesium and nitrogen on the growth and yield of white and Indian mustard seeds. Rosliny Oleiste, 22(1), 45-58.

Cakmak, I., Romheld V., 1997. Boron deficiency induced impairments of cellular functions in plants. Plant and Soil, 193, 71-83.

Dabhi, M. K., Gupta, D. G., Patel, J. J., 2010. Response of sulphur application on growth, yield attributes and yield of mustard under middle Gujrat conditions. Green farming, 1(3), 272273.

Dear, B. S., Lipsett, J., 1987. The effect of boron supply on the growth and seed production of subterranean clover (Trifolium subterraneum L.) Australian Journal Agriculture Research, 38, 537546.

Directorate of Economics and Statistics, Department of Agriculture and Cooperation, 2012-13.

DRMR (2011). VISION 2030. Directorate of Rapeseed-Mustard Research, Bharatpur 321303 Rajasthan. Pp 30.

Frommer, W. B., N. Von Wiren., 2002. Plant biology Ping Pong with boron. Nature, 420 (6913), 282-283.

Hassan, A. M., and Malhi, S. S., 2011.Phenology and seed quality response of rape (B. napus) versus mustard (B. juncea) to sulphur and potassium fertilization in northwest 
Pakistan. Journal of Plant Nutrition, 34(8), 1175-1185.

Holmes, M.R.J., 1980 Nutrition of the Oilseed Rape Crops, Applied Science Publishers, Essex, U K, 1980, In TSI/FAI/IFA Symposium.

Hossain, M.A., Jahiruddin, M., Khatun, F., 2011.Effect of boron on yield and mineral nutrition of mustard (Brassica compestris). Bangladesh Journal of Agriculture Research.

Katyal, J. C., Sharma, K. L., Srinivas, K., 1997. Sulphur in Indian agriculture. Proceedings of the TSI/FAI/IFA Symposium on Sulphur in Balanced Fertilisation, KS-2/1-KS-2/12.

Khan N., Jan A., Ihsanullah I., Khan, A., Khan, N., 2002. Response of canola to nitrogen and sulphur nutrition. Asian Journal of Plant Sciences, 1, 516-518.

Khan, N.A., Mobin, Md., Singh, S., 2008.Effects of gibberellic acid and sulphur on yield efficiency of mustard. Advances in Plant Physiology, 10, 455461.

Kumar, R., Singh, D., Singh, H., 2002. Growth and yield of Brassica species as influenced by sulphur application and sowing dates. Indian Journal of Agronomy, 47(3), 418-421.

Kumar, R., Singh, V.Y., Singh, S., Latare, M.A., Mishra, P.K., Supriya, 2012. Effect of phosphorus and sulphur nutrition on yield attributes, yield of mungbean (Vigna radiata). Jouranl of Chemical and Pharmaceutical Research, 4(5), 2571-2573.

Lal, M., Singh, D. P., 2012. Effect of nitrogen sources, sulphur and boron levels on growth parameters of spring sunflower (Helianthus annus L.). Annals of Agriculture Biology Research, 17(1), $19-26$

Matoh, T., (1997). Boron in plant cell walls. Plant and soil, 193, 59-70.
Mengel, K. and Kirkby, E.A., 1987. Principles of plant nutrition. International Potash Institute, Switzerland.

Nagaraj, G., 1995. A Text Book of Quality and Utility of Oilseeds. The Project Director, Directorate of Oilseed Research, Rajendranagar, Hyderabad, 500030.

NIIR Board. Hand book on Herb Cultivation and Processing. Asia Pacific Business Press Inc. Regd. Office: 106 -E Kamala Nagar, Delhi 110007 (India). Page 90.

Noppakoonwong, R. N., Rekasem, B., Bell, R. W., Dell, B., Loneragan, J. F., 1997. Prognosis and diagnosis of boron deficiency in black gram (Vigna mungo L.) in the field by using plant analysis. In boron in soils and plants. Eds. R. W. Bell and R., Rerkasem. Kluwer Acad, Pub., Dordrecht. The Netherlands.

O’Neill, M. A., T. Ishii., P. Albersheim, A. G. Darvill., 2004. Rhamnogalacturonan II: structure and function of borate cross linked cell wall pectic polysaccharide. Annals Review Plant Biology. 55, 109139.

Rashid, M. H., Hasan, M. M., Ahamad, M., Rahaman, M. T., Rahaman, K. A. M. M., 2012. Response of mustard to boron fertilization, Bangladesh Journal of Agriculture Research, 37(4), 677-682.

Sahu, B., Kwatara, V., Nema, M. L., 2004. Response of mustard, Brassica juncea (L.) Czern and Coss. To phosphorus and sulphur levels in rice lowlands. Journals of Oilseeds Research, 21(1), 181-182.

Sarkees, N. A. (2013). Response of growth, yield and oil of rapseed to sowing method and seeding rate. Journal of Agricultureand Veterinary Science, Volume 3, Issue 1, PP 01-06.

Sharma, A., Gupta, R., Kumar, A., 2008. Effect of sowing methods, nitrogen and sulphur level on growth, yield and oil 
contents of mustard (Brassica juncea). Plant Archives, 8(1), 421-424.

Singh, S. P., Bansal K. N., 1999. Influence of nitrogen, its application time and sulphur on nitrogen, phosphorus and sulphur uptake by soybean (Glycine max). Haryana Journal of Agronomy, $15,30-34$.

Takano, J., K. Noguchi., M. Yasumori., M. Kobayshi., Z. Gajdos., K. Miwa., H. Hayashi., T. Yoneyama, T. Fujiwara. 2002. Arabidopsis boron transporter for xylem loading. Nature, 420 (6913), 337340.

Tomar, S. K., Singh, K., 2007. Response of Indian mustard (Brassica juncea L.) to nitrogen and sulphur fertilization under rainfed condition of diaraland. International Journal of Agricultural Sciences, 3(2), 5-9.

Verma, C.K., Prasad, K., Yadav, D.D., 2012. Studies on response of sulphur, zinc and boron levels on yield, economics and nutrients uptake of mustard [Brassica juncea (L.) Czern \& Coss.] Crop Research (Hisar), 44(1/2), 75-78.

Verma, S. K., Singh, S. K., Singh, T. K., 2009.Effect of nitrogen and sulphur on growth, yield and nutrient uptake by Indian mustard (Brassica juncea) under rainfed condition. Indian Journal of Agricultural Sciences, 79(8), 648-650.

\section{How to cite this article:}

Hemkalyan Verma and Joy Dawson. 2018. Response of Sowing Methods and Different Levels of Sulphur and Boron on Growth and Yield of Yellow Sarson (Brassica compestris L.). Int.J.Curr.Microbiol.App.Sci. 7(03): 1558-1564. doi: https://doi.org/10.20546/ijcmas.2018.703.186 